Abstracta Iranica

Revue bibliographique pour le domaine irano-aryen

Volume 32-33 | 2013

Comptes rendus des publications de 2009-2010

\title{
Enrico G. Raffaelli. The Astrological Chapter of the škand Gumânîg Wizâr
}

\section{Živa Vesel}

\section{(2) OpenEdition}

1 Journals

Édition électronique

URL : http://journals.openedition.org/abstractairanica/40717

DOI : 10.4000/abstractairanica.40717

ISSN : 1961-960X

\section{Éditeur :}

CNRS (UMR 7528 Mondes iraniens et indiens), Éditions de l'IFRI

\section{Édition imprimée}

Date de publication : 1 décembre 2013

ISSN : 0240-8910

\section{Référence électronique}

Živa Vesel, « Enrico G. Raffaelli. The Astrological Chapter of the Škand Gumânîg Wizâr », Abstracta Iranica [En ligne], Volume 32-33 | 2013, document 401, mis en ligne le 01 juillet 2016, consulté le 03 octobre 2020. URL : http://journals.openedition.org/abstractairanica/40717 ; DOI : https://doi.org/ 10.4000/abstractairanica.40717

Ce document a été généré automatiquement le 3 octobre 2020.

Tous droits réservés 


\title{
Enrico G. Raffaelli. The Astrological Chapter of the Škand Gumânîg Wizâr
}

\author{
Živa Vesel
}

\section{RÉFÉRENCE}

Enrico G. Raffaelli. « The Astrological Chapter of the Škand Gumânîg Wizâr », in : G. Gnoli \& A. Panaino, eds., Kayd. Studies in the History of Mathematics, Astronomy and Astrology in Memory of David Pingree. Rome, IsIAO, 2009, p. 105-127.

1 Škand, l'œuvre apologétique du IX ${ }^{\mathrm{e}}$ s. en pehlevi (transmise en pâzand), contient un chapitre important sur l'astrologie et expose l'idée bien connue de la lutte cosmique entre les corps célestes bénéfiques (les étoiles fixes, le soleil et la lune) et maléfiques (les planètes et les comètes) dans le cadre zoroastrien. Le contenu reproduit, entre autres, l'adaptation d'éléments indiens dans le monde iranien (l'introduction des nœuds lunaires parmi les planètes, l'idée des « cordes » qui lient les planètes aux deux luminaires, etc.), ou des éléments rarement transmis par les textes pehlevi (la doctrine astrologique de l'influence des constellations du zodiaque et des planètes sur les régions et les villes). L'A. postule la ressemblance entre le chap. 4 du Škand et la section 5 de Bundahišn et leur attribue comme origine commune la version commentée pehlevi de l'Avesta. 


\section{AUTEURS}

ŽIVA VESEL

CNRS, Mondes iranien et indien, Paris 